\title{
Analysis of the Cost-Effective Road Maintenance Program for the Improvement of Road Value in Kabupaten Gresik Using the Forecasting Method
}

\author{
Dhiannita Tri Astuti ${ }^{1}$ and I Putu Artama Wiguna ${ }^{2}$ \\ ${ }^{1}$ Department of Technology Management, Institut Teknologi Sepuluh Nopember, Surabaya \\ ${ }^{2}$ Department of Civil Engineering, Institut Teknologi Sepuluh Nopember, Surabaya \\ e-mail:dhiannita9@gmail.com
}

\begin{abstract}
Roads have a very significant role in enhancing various fields as part of the national transport network. Road management includes road construction, improvement, and technical maintenance activities, which are continuously carried out for the physical maintenance of the road. The role of the road service must be fulfilled so as not to compete with the transportation that passes on the road. Based on the phenomena that have been described, we present the analysis of the cost requirements and methods of road handling in addition to the effectiveness of road stability for the next two years. The research was carried out for a case study of the district major road in Gresik Regency, which is represented in this situation by three main roads. The analysis of a data set is based on the variables of historical data. Then, we analyze using time series with moving averages, exponential smoothing, and trend projection. Next, the method for setting a maintaining strategy of overcoming prediction and its relation to the solidity of the roads, using fuzzy tahani. The results analyzed are confirmed by the recommended output for the next two years.
\end{abstract}

Keywords-Exponential Smoothing, Fuzzy Tahani, Moving Averages, Roads Management Prediction, Trend Projection.

\section{INTRODUCTION}

$\mathrm{R}$ OADS as part of the national transportation system have an important role especially in supporting the economic, social and cultural and environmental fields and are developed through a regional development approach to achieve equilibrium and equitable development among regions, form and strengthen national unity to strengthen national defense and security, and form structures space in order to realize national development goals [1]. The road handling program must be carried out effectively and efficiently in terms of functions and costs, so it is necessary to optimize future planning for road handling in Gresik Regency. Nearly one-third of the Gresik Regency region is a coastal area and has been known as an Industrial City. This condition makes the roads in the Gresik area quite crowded with goods and mass transport vehicles as well as the main transportation route for the north coast of Java (Pantura). This figure does not include the Village Axis Road Network, Village Roads and Environmental Roads, which are also the responsibility of the Gresik Regency Government. In this paper, we took a sampling of district roads whose management is under the authority of the Bina Marga Division of the Gresik Regency Dinas Pekerjaan Umum dan
Tata Ruang which is the locus of this study.

In regional development and the rapid economic development that occurred in Gresik Regency, it is not yet comparable to infrastructure development including roads as connectivity facilities and the main support of community activities for the transportation of people, goods, and services. In previous studies, it has been described in the Journal of Analysis of cost-effective treatment and budget optimization for arterial roads in the city of Chattanooga [2], that in handling some work it is necessary to analyze the most important thing is in terms of finance.

With the same clear idea model, we can describe in this study a broader scope, namely the planning of implementation and the appropriate model or procedure for handling road works in the order of priority management. The assessment will be carried out evenly with an index of 0 to 100 according to the data held in the past few years. In this paper, research will be carried out with limited objects with different conditions on three main roads in Gresik Regency that can represent road conditions and the environment in Gresik Regency, including: (1) RE Martadinata Road Section; (2) Driyorejo - Lakarsantri Road Section; and (3) Cerme - Metatu Road Section.

With an appropriate prediction plus planning and readiness to implement, it is anticipated that public road facilities will be a factor that will reduce the community at a large impact on the implementation of the economy. Furthermore, with the prediction, we can arrange an appropriate handling strategy to overcome these problems, so that it is expected that based on the span of two years we can prepare the right planning from the budget and also the type of treatment.

This means allowing efficiency to be achieved and minimizes errors that may occur and budget waste that is not appropriate and appropriate to the target. In this prediction process, we will use a quantitative approach with a time series model and sorting priority handling with fuzzification. From the two data or forecasting models will get the main data which is in the form of predictions that must be made or recommendations in the next two years. In the prediction needed supporting data that is prepared to make a predetermined model can be run in accordance with the theory and some literature that has been done previous research. In this study, we will try to prepare all the data and also project the data into a prediction that can be useful. 
The $6^{\text {th }}$ International Seminar on Science and Technology (ISST) 2020

July $25^{\text {th }} 2020$, Institut Teknologi Sepuluh Nopember, Surabaya, Indonesia

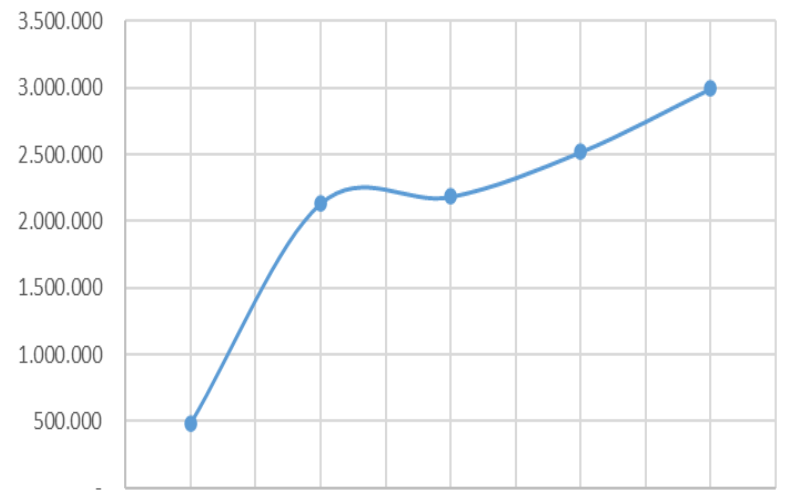

2015,52016 2016,5 20172017,52018 2018,5 20192019,52020 2020, Figure 1. LHR diagram.

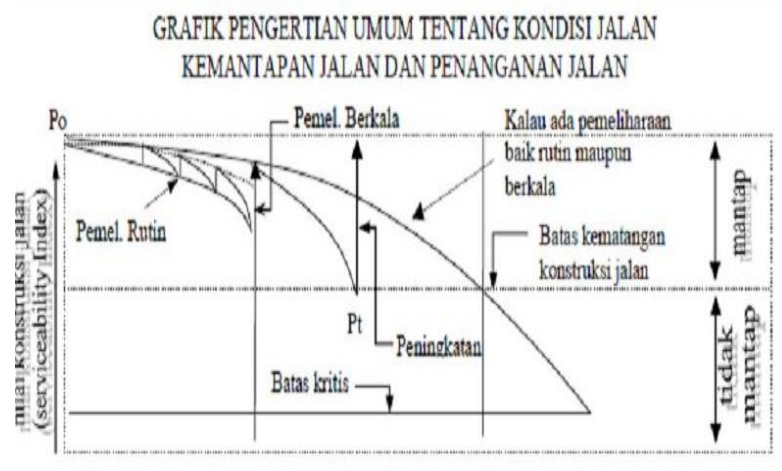

MASA PELAYANAN JALAN

$\mathrm{P}_{0}=$ Nilai Konstruksi awal Seviceability Inder awal (banu)

$\mathrm{Pt}=$ Nilai Konstruksi Serviceability Index Ahir (batas kemantapan)

Nilai Po dan Pt Tergantung pada klasifikasi jalan (N, P, K) serta LHR

Figure 2. Pekerjaan Umum Data Chart.

The remainder of this paper is structured as follows: Section 2 shows the related works. Section 3 demonstrates the research methodology. Section 4 evaluates the methodology. Then, Section 7 concludes this paper with future works.

\section{RELATED WORKS}

In the implementation of road construction works, the most influential factor is the availability of costs. The costs required for road handling are not unlimited, so effective and efficient cost planning is needed, but it still meets the needs of the community for smooth transportation with stable district road conditions. Therefore this study was conducted to analyze the cost of the need for road handling in the next few years that meet the target of road stability in accordance with the Gresik District Renstra using prediction methods and determining treatment priorities according to applicable regulations [3].

In this section, we briefly discuss related works to this paper. Analyzes cost-effective pavement maintenance and optimize the budget for arterial roads in the city of Chattanooga, Department of Civil Engineering, the University of Tennessee at Chattanooga, Chattanooga TN 37403, USA. The Pavement Management System (PMS) has been shown as an important tool for proper infrastructure management and proper use of available funds. The University of Tennessee at Chattanooga uses Micropaver software as a PMS tool to conduct an analysis of major

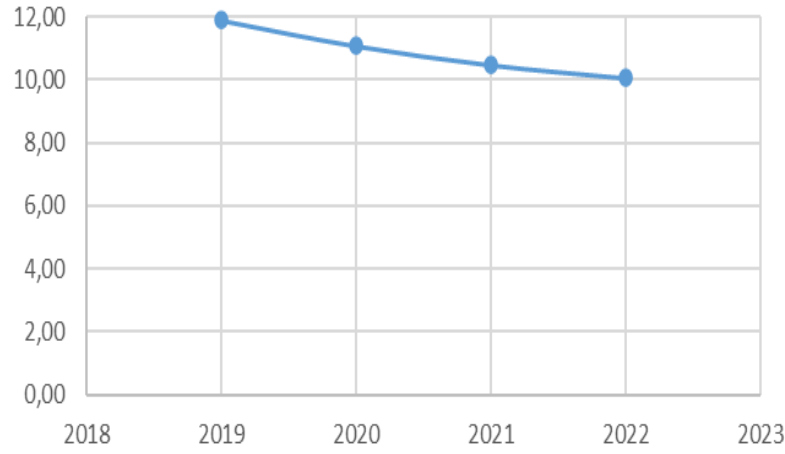

Figure 3. LHR forecasting condition.
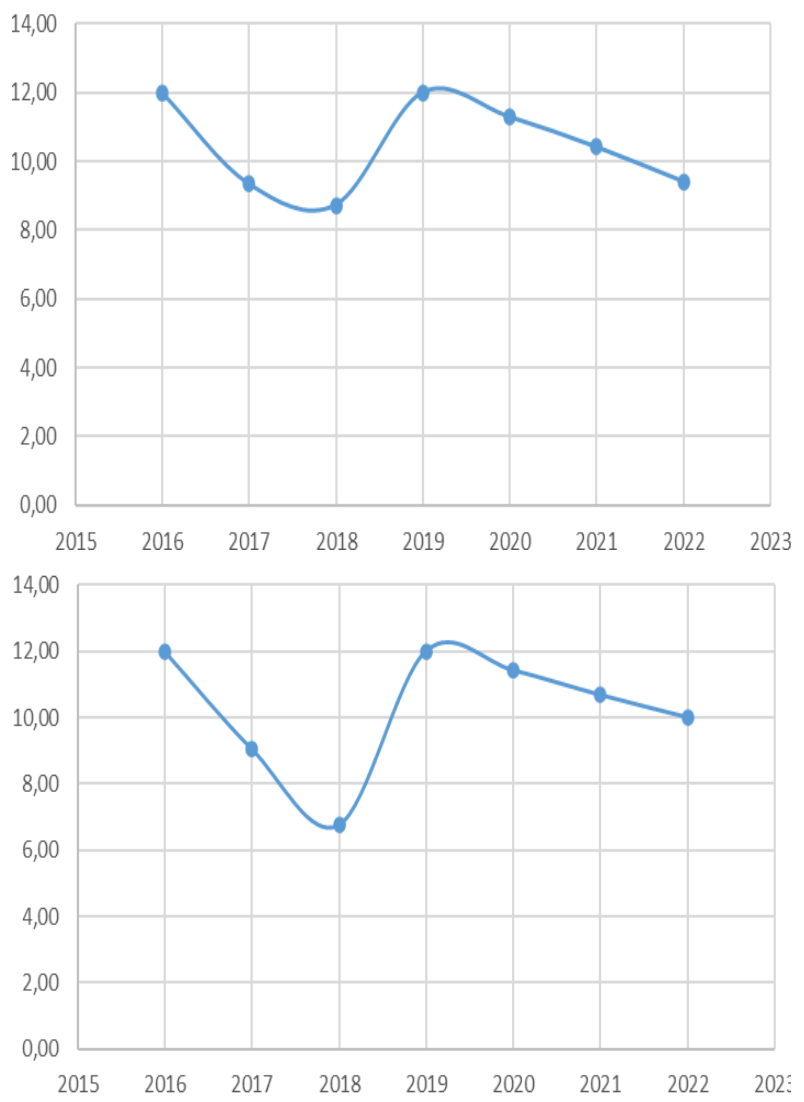

Figure 4. LHR forecasting condition Driyorejo - Lakarsantri and Cerme - Metatu.

arterial pavement management in the City of Chattanooga. This study uses the Chattanooga City pavement database to create current and future pavement conditions. Maintenance and repair planning $(\mathrm{M} \& \mathrm{R})$ analyzes are also carried out to determine the most cost-effective maintenance and suggest optimal use of funds for the city. The budget analysis scenario is carried out for the five-year plan using the pavement condition index (PCI) method (ASTM D 6433-11). The results show that the deletion budget will be the best scenario because it improves pavement conditions and eliminates major maintenance arrears and repairs over a five-year period. An unlimited budget seems ideal, but it does not improve pavement conditions. Maintaining current conditions and limited budget scenarios will increase savings and total maintenance and repair costs during the analysis period [2].

Optimizes new pavement maintenance strategies: Case studies for national road networks in Indonesia using 
The $6^{\text {th }}$ International Seminar on Science and Technology (ISST) 2020

July $25^{\text {th }} 2020$, Institut Teknologi Sepuluh Nopember, Surabaya, Indonesia

Table 1.

Vehicle Classifications

\begin{tabular}{|c|c|c|c|c|}
\hline No. & Type & Notes & $\begin{array}{c}\text { Weight } \\
(\mathrm{Kg})\end{array}$ & Weighted \\
\hline 1 & MV & $\begin{array}{l}\text { Motorcycle, Scooters, } \\
\text { Beetle Bikes, and } 3 \\
\text { Wheels }\end{array}$ & 100 & 2 \\
\hline 2 & LV & $\begin{array}{l}\text { Sedan, Jeep, Station } \\
\text { and Taxi (Private) }\end{array}$ & 3500 & 70 \\
\hline 3 & LV & $\begin{array}{l}\text { Opelet Pich-up, } \\
\text { Suburban, Combi, } \\
\text { Minibus (MPU and } \\
\text { Angkot) }\end{array}$ & 3500 & 70 \\
\hline 4 & LV & $\begin{array}{l}\text { Pick-ups, Micro } \\
\text { Trucks, Conducting } \\
\text { Cars and Rear Tires } \\
\text { Trucks } 1\end{array}$ & 3500 & 70 \\
\hline 5 & HV & Small Bus & 4500 & 90 \\
\hline 6 & HV & Big Bus & 7000 & 140 \\
\hline 7 & HV & $\begin{array}{l}\text { Trucks / Boxes, Tank } \\
\text { Truck } 2 \text { Axis } 3 / 4\end{array}$ & 12.000 & 240 \\
\hline 8 & HV & $\begin{array}{l}\text { Truck / Box, } 2 \text { Axis } \\
\text { Tank Truck }\end{array}$ & 16.000 & 320 \\
\hline 9 & HV & $\begin{array}{l}\text { Trucks / Boxes, } 3 \text { Axis } \\
\text { Tank Trucks }\end{array}$ & 22.000 & 440 \\
\hline 10 & HV & $\begin{array}{l}\text { Tank Trucks / Tank } \\
\text { Collaborators }\end{array}$ & 34.000 & 680 \\
\hline 11 & HV & $\begin{array}{l}\text { Semi-Trailer Truck and } \\
\text { Trailer Truck }\end{array}$ & 40.000 & 800 \\
\hline 12 & UM & $\begin{array}{l}\text { Non-Motorized } \\
\text { Vehicles and Carts }\end{array}$ & 50 & 1 \\
\hline
\end{tabular}

integrated road management systems. Road infrastructure contributes to facilitating the distribution of goods and services to improve the quality of human life. The road network requires maintenance in the form of maintenance to keep the road in good condition so that it can function as a provider of access and comfort. Road maintenance must always be planned to provide maximum security for road users in a cost-effective manner. It is very important for the person in charge of the road to use the budget efficiently and effectively in keeping the road in good condition during service. These obstacles seem to often occur to those responsible for road conditions that must be decided on the level of damage and type of maintenance [4].

Optimizes the Road Maintenance Model Based on Dynamic Programming in Urban Traffic Networks. Urban road maintenance is an important part of urban traffic management. However, in modern cities, road maintenance works need to occupy some traffic resources; therefore, less systematic road maintenance schemes often cause traffic networks to experience unexpected large-scale congestion. In this paper, a dynamic programming model is proposed to minimize delays caused by road maintenance schemes. This model can obtain a global optimal maintenance scheme that contains decisions and sequences for each maintenance phase. Each stage of this model can be summarized into a discrete network design problem. This model helps make suggestions for traffic managers by minimizing requests caused by maintenance schemes. This paper uses two examples to illustrate this method, one is the small-scale Nguyen-Dupuis network, and the other is the larger-scale Sioux-Falls network [5].

Uses the fuzzy analytic hierarchy process (FAHP) method and the TOPSIS method to determine district road priority priorities Road handling priorities are considered to be a complex multi-criteria decision-making problem. The Analytic Hierarchy Process (AHP) has long been used to consider problem criteria. But blurring and obscurity are generally found in many decision-making problems. To overcome this, fuzzy sets are combined with pairwise comparisons as an extension of AHP. This study uses the Fuzzy Analytic Hierarchy Process (FAHP) method and TOPSIS to determine priority handling of highways for damaged roads in Bangli Regency, Bali. Data were taken from previous studies using AHP and SK.NO.77 / KPTS / Db / 1990 from the Directorate General of Highways to determine priorities for handling Bangli district roads. In this study, the weight of the main criteria and sub-criteria was determined by FAHP and then the ranking of the road rank was determined by the TOPSIS method. Based on previous studies, the AHP method yields different results from the method 'SK.NO.77 / KPTS / Db / 1990 'for priority handling of district roads from damaged roads in Bangli District. The study concludes that for top priority (ie first and second rank), the FAHP and TOPSIS methods provide results that are quite close to 'SK.NO.77 / KPTS / Db / 1990 however but somewhat different from AHP. This is perhaps best explained by the fact that economic factors are considered as the main factors in using the FAHP method and 'SK.NO.77 / KPTS / $\mathrm{Db} / 1990$ '. However, the FAHP and TOPSIS methods are preferred over the AHP and SK.NO.77 / KPTS / Db / 1990 methods in determining priority handling of district roads in Bangli district [6].

Implements a Cut-Based Fuzzy Analytic Hierarchy Process (FAHP) and TOPSIS Method to Determine the Priority of Handling Bali Province Roads, the Analytic Hierarchy Process (AHP) method has been used in previous research to determine priority handling of Bali provincial roads. This method usually ignores the level of trust and optimism of the decision-maker. Meanwhile, $\alpha$-cut-based Fuzzy Analytic Hierarchy Process (FAHP) and Techniques for Order Preference with Similarity to Ideal Solutions (TOPSIS) methods allow researchers to estimate priorities for handling overall paths considering the level of confidence and optimism of decisions. This study aims to determine the priority of handling the Bali provincial road using the $\alpha$-cut FAHP method and the TOPSIS method. The current study shows that the level of confidence of decision-makers in pessimistic and moderate situations and optimism from certain conditions to the most uncertain conditions shows the same road relationship with the highest priority compared to previous studies. Both the current and previous studies also conclude the same road relationship with the lowest priority handling of the road [7].

\section{RESEARCH METHODOLOGY}

The data needed in this study are primary data and secondary data. Primary data were obtained from roadhandling historical data in Gresik Regency 5 (five) years backward. Primary data is data taken directly from research subjects as respondents. The data collection process was carried out directly from the Archives of the Bina Marga 
The $6^{\text {th }}$ International Seminar on Science and Technology (ISST) 2020

July $25^{\text {th }} 2020$, Institut Teknologi Sepuluh Nopember, Surabaya, Indonesia

Table 2.

Cost value 2016-2020

\begin{tabular}{|c|c|c|c|}
\hline & & " Cost value 2016-2020 & \\
\hline \multirow{5}{*}{ RE. Martaadinata } & 2016 & $\begin{array}{ll}\text { Rp. } & 200.000 .000\end{array}$ & Routine maintenance \\
\hline & 2017 & Rp. 2.060.200.000 & Periodic maintenance \\
\hline & 2018 & Rp. $\quad 200.000 .000$ & Routine maintenance \\
\hline & 2019 & Rp. 8.420.202.167 & Enhancement \\
\hline & 2020 & Rp. 200.000 .000 & Routine maintenance \\
\hline \multirow{5}{*}{ Driyorejo - Lakarsantri } & 2016 & Rp. 4.105 .000 .000 & Enhancement \\
\hline & 2017 & Rp. 200.000 .000 & Routine maintenance \\
\hline & 2018 & $\begin{array}{ll}\text { Rp. } & 200.000 .000\end{array}$ & Routine maintenance \\
\hline & 2019 & Rp. 4.105.000.000 & Enhancement \\
\hline & 2020 & Rp. 4.105.000.000 & Enhancement \\
\hline \multirow{5}{*}{ Cerme - Metatu } & 2016 & Rp. 3.781.679.000 & Enhancement \\
\hline & 2017 & 0 & \\
\hline & 2018 & Rp. 4.788.215.300 & Enhancement \\
\hline & 2019 & Rp. 8.111.670.000 & Enhancement \\
\hline & 2020 & Rp. 7.450 .078 .082 & Enhancement \\
\hline
\end{tabular}

Table 3.

Prediction in 2021

\begin{tabular}{lcc}
\hline \multicolumn{1}{c}{ Road Section } & Project in 2021 & $\begin{array}{c}\text { Condition in } \\
\mathbf{2 0 2 1}\end{array}$ \\
\hline RE. Martadinata & $\begin{array}{c}\text { Routine } \\
\text { maintenance } \\
\text { Routine }\end{array}$ & Baik \\
$\begin{array}{l}\text { Driyorejo - } \\
\text { Lakarsantri }\end{array}$ & $\begin{array}{c}\text { maintenance } \\
\text { Routine } \\
\text { Cerme - Metatu }\end{array}$ & Baik \\
\hline \hline
\end{tabular}

Departement Pekerjaan Umum dan Tata Ruang in Gresik Regency. While secondary data is data from previous research, regulations, and technical guidelines by the Ministry of Public Works, Regional Regulations in Gresik Regency and supporting data for the validity of research objects, in the form of literature and formal legal documentation relating to the research object.

Table 1 shows In its implementation in each type of vehicle has its respective weights so that the next stage of the collection is the stage for collecting data for vehicle classification. Then table 2 represent what has to be there in the history of the handling of the road that has been done along with its costs.

With this problem, we need a perfect prediction in reviewing the needs that must be addressed. In this process with existing data, we need to predict what happens at least the next 2 years in order to give time in planning roadhandling strategies that can improve road conditions in good and moderate conditions (steady). Any information that really needs to be collected in order to support the data that will be carried out in this study. That way we have several portions of work that need to be prepared to support the method for each object quantitatively including:

a. LHR, daily traffic of road users.

b. Road Condition Data.

c. Road stability figures.

d. Road Handling for the Last 5 Years : (1) volume; (2) costs; (3) time; (4) tpe of asphalt pavement.

The equation used in this study for the quantitative method is the time series method with linear regression, using a time series arranged per year

$y=a+b x$

$b=\frac{n \sum x y-\sum x \sum y}{n \sum x^{2}-\left(\sum x\right)^{2}}$ $a=\frac{\sum y-b \sum x}{n}$

$x$ : data on the $\mathrm{x}$-axis or year.

$y$ : history data on the $y$ axis.

$a$ : intersection with upright axis.

$b$ : expresses the slope or slope of the regression line.

\section{ANALYSIS AND RESULT}

In this section stage, the data that has been obtained are arranged so as to obtain a table that includes the whole, for each variable it will be calculated first by using quantitative three types of curves, namely moving averages, exponential smoothing, and also trend projection. Specifically for LHR, the average for each type of vehicle will be calculated in one year, then a quantitative method is implemented for each stage. From the data obtained above it will be multiplied by the weight that has been determined, and then in the amount will be entered into the quantitative stage shown in Figure 1.

In theory from Pekerjaan Umum data, there is a decline where every year there is a decrease that must be done to maintain maintenance to improve road conditions, although not $100 \%$. So the parameter to be used is the cost which represents the rising trend for the road, shows in Figure 2.

In reality, the field needs to be maintained so that road conditions become longer in life. And there are a decrease (differential) conditions that can be formulated as the best condition devided roads planning ages. Then obtained a value per year is 0.6 , so that when the 5 th year it has decreased by 3 numbers to 9 this condition if indeed the LHR is in accordance with the planned increase, if not then the differencing will be compared with the previous year's LHR. Then, Figure 3 illustrates the LHR forecasting that has been provided.

Next, entered into the forecasting formula where the requirements of the system determine the data in the following year. Then we will get a graph of the points before we juxtapose with the financing that has been done. This is so that original data can be identified if maintenance or upgrading of roads is not done at all.

From Figure 4, it is the condition data that we got from the last increase up to the forecasted year. There are actually unfavorable conditions due to a very drastic decline occurring here, and then the financing that has been done by the Gresik 
The $6^{\text {th }}$ International Seminar on Science and Technology (ISST) 2020

July $25^{\text {th }} 2020$, Institut Teknologi Sepuluh Nopember, Surabaya, Indonesia

Regency Binamarga. If we assume that an increase will make conditions better or worth 12, the graph we get is as follows. And for 2021, only maintenance needs to be done, to better maintain the existing road conditions on the Driyorejo Lakarsantri road section, then we will see a graph of the Cerme - Metatu road section

There is a point in 2018 where the road is slightly damaged, and for forecasting in 2021 the charts for the Cerme - Metatu Road need maintenance. That way we can give conclusions for these three roads, having the need for 2021 in table 3.

\section{CONCLUSION}

Based on the results of the analysis of this study, it can be concluded. The condition of the road will always decrease every year even after maintenance is carried out because the decrease depends on the LHR or the vehicle that passes the road. Then, There is a decreasing variable that can be investigated as a coefficient. Also, The road needs for 2021 can be carried out according to the forecasting that has been done. Finally, The needs of each road vary according to regional characteristics. For the next research, we will continue the data used can be detailed per STA / Station for financing so forecasting is per STA / Station and added trend projections as seasonal conditions that help reduce road conditions.

\section{REFERENCES}

[1] “Undang-undang Republik Indonesia no 38 Tahun 2004", President of the Republic of Indonesia, 2004.

[2] M. Onyango, S. A. Merabi, J. Owino, I. Fomunung, and W. Wu, "Analysis of Cost Effective Pavement Treatment and Budget Optimization for Arterial Roads in the City of Chattanooga," Front. Struct. Civ. Eng., vol 12, pp. 291-299, Aug 2017.

[3] "Undang-undang Republik Indonesia no 38 Tahun 2008", President of the Republic of Indonesia, 2008.

[4] Hamdi, S. P. Hadiwardoyo, A. G. Correia, and P. Pereira, "New Optimization Strategies of Pavement Maintenance: A Case Study for National Road Network in Indonesia using Integrated Road Management System," in Proceedings of the 3rd International Conference on Engineering, Technology, and Industrial Application Green Process, Material, and Energy: A Sustainable Solution for Climate Change, ICETIA 2016.

[5] J. Ma, L. Cheng, and D. Li, "Road Maintenance Optimization Model Based on Dynamic Programming in Urban Traffic Network," Journal of Adv. Transportation, vol. 2018, Jun 2018.

[6] D. M. P. Wedagama "Determining Regencial Road Handling Priority Using Fuzzy Analytic Hierarchy Process (FAHP) and TOPSIS Method (Case Study: Badung Regency - Bali)," Jurnal Teknik Sipil Insstitut Teknologi Bandung, vol. 17, no. 2, pp. 143-152, Aug. 2010.

[7] D. M. P. Wedagama and A. Frederika, "Applying Fuzzy Analytic Hierarchy Process (FAHP) $\alpha$-Cut Based and TOPSIS Methods to Determine Bali Provincial Road Handling Priority," Journal of civil engineering science and application, vol. 13, no. 2, pp 98-106, 2011. 